Regular Research Article

\title{
Reducing Emissions, Forest Management and Multiactor Perspectives: Problem Representation Analysis of Laos REDD+ Programs
}

\author{
Herlin Chien ${ }^{1, *}$ \\ ${ }^{1}$ National Pingtung University of Science and Technology, Taiwan; United Nations University, Institute for \\ the Advanced Study of Sustainability, Japan. \\ * Correspondence author: hchien@mail.npust.edu.tw
}

\begin{abstract}
Every policy solution is embedded in a certain "problem representation" that is taken for granted and assumed by policymakers. This paper examines how emission reductions and forest management have been problematized for policymaking and solution implementation from multiple actors' perspectives. Reducing Emissions from Deforestation and Forest Degradation (REDD+), particularly Forest Carbon Partnership Facility (FCPF) programs, in the Lao People's Democratic Republic (Lao PDR) serves as a demonstrative example. By applying the 'What is the Problem Represented to be' (WPR) approach as a poststructuralist method, this study first comparatively analyzes the general problem as represented by multiple actors, including the government, media, academia and civil society. In particular, queries such as what and how the "problem" is represented and what is not problematized are reflected during the analyses. Next, this research further examines the corresponding problematization gap based on drivers of deforestation and forest degradation and discusses the noncarbon benefits of FCPF in the rhetoric. The objective of the study is to not to find the best policy choice but to reveal the heterogeneity in problem representations formulated by multiple actors to yield space for alternative and disruptive change for future problem solving in emission reductions and forest management.
\end{abstract}

Keywords: FCPF; Lao PDR; forest management; problematization; REDD+

\section{Introduction}

Science-based evidence, including the authoritative reports released by the Intergovernmental Panel on Climate Change (IPCC AR5, Pachauri et al., 2014), has increasingly confirmed the strong causal linkage between climate change and anthropogenic pressure on forests (Foley et al., 2005; Stern, 2007). In 2015, Federici and his research team updated the state of knowledge on global

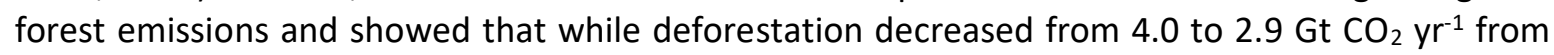
1991-2000 to 2011-2015, emissions from forest degradation have increased from 0.4 to $1.0 \mathrm{Gt} \mathrm{CO}_{2}$ $\mathrm{yr}^{-1}$ (Federici et al., 2015). In the same year, the conference of parties (COP) concluded the long negotiations associated with incorporating the Reducing Emissions from Deforestation and Forest Degradation (REDD +, Article 5.2) program into the global climate regime (UNFCCC 2016 ${ }^{1}$ ). In essence, the REDD is the largest payment for ecosystem services (PES) (Corbera, 2012) and aims to provide a financial incentive for participating members to restore and improve the capacity of tropical forests as an important carbon sink.

Despite the benign intention to improve forest management to mitigate climate change, scholars have described REDD+ as a controversial global program (McGregor et al., 2014) that may promote market rationales in decision-making (Pearse, 2012) and neglect nonmarket value or decouple social and cultural ties from economic benefits (Büscher et al., 2012). REDD+ is also regarded as a contentious issue for academics, nongovernmental organizations (NGOs) and forest communities, who have debated its pros and cons (McGregor, 2010) and the issues that should be "problematized"(Cavanagh et al., 2015; Corbera, 2012) before corresponding action can follow.

${ }^{1}$ https://unfccc.int/resource/docs/2015/cop21/eng/10.pdf (accessed on October 14, 2019) 
Due to the controversial and contentious nature of REDD+, this study focuses on how the problem of deforestation and forest degradation is constructed by different actors and argues that the representation construct of the problem by this nascent carbon reduction policy instrument must be critically evaluated. Specifically, the research proposes the use of the "What is the Problem Represented to be?" (WPR) approach (Bacchi, 2009; Bletsas and Beasley, 2012) as a tool to unravel the inherently political policy-making process (Keeley, 2001) to include or exclude different interests and actors. In the extant literature, the application of problem representation to analyze REDD+ is still limited. Yeboah (2013) from Swedish University of Agricultural Science demonstrated that analyzing forest policy as a discourse via the WPR is helpful for understanding how gender is configured and may vary among state or nonstate actors in Ghana. By using the same poststructuralist method, Baledón and Kosoy (2018) explored how carbon emissions from international aviation were problematized to identify options for disrupting the existing structure in favor of more progressive mitigation and adaptation strategies.

In other words, the WPR method can be useful not only in unraveling the socially constructed structure that each REDD+PES scheme is built upon but also in promoting future improvements to involve multiple actors whose problem representation constructs are currently marginalized or excluded. This latter function of the WPR is particularly pivotal for REDD+ since the need to include different actors is recursively emphasized as an important criterion for the effective implementation of multilevel forest management governance (Forsyth, 2009).

To showcase the potential of the WPR to improve the effectiveness of REDD+ governance in multiactor collaboration and encourage policy reflection, this study investigated the Lao People's Democratic Republic (Lao PDR), which is the Southeast Asian country that presented the highest forest cover ( $70 \%$ of land area) in the $1940 \mathrm{~s}^{2}$ and has exhibited a challenging deforestation problem, with an annual loss of 21,900 hectares of forest in 1990 and 75,150 hectares in 2010³. With the support of international donors, Laos was an early participant of REDD+ shortly after its official proposal in 2005 and joined the Forest Carbon Partnership Facility (FCPF) in 2007 with the goal of achieving $70 \%$ forest cover over the total land area by 2020 . However, the Forestry Strategy to the Year 2020 in the Lao PDR might fail ${ }^{4}$ and the overall strategy must be evaluated; thus, a problem representation analysis method, such as WPR, is warranted.

The following sections begin with a further explanation of the theoretical framework on problem representation, which is followed by an introduction of the Laos REDD+ context and the problem representation analysis method designed to identify problematization gaps in the Laos REDD+ from multiple sources, including REDD+-related Laos country reports, online news, academic articles and NGOs reports. The remainder of the paper proceeds through three stages of critical problem representation analyses to reflect the "problem" formation based on the 1) general REDD+, 2) drivers of deforestation and forest degradation (DD), and 3) noncarbon benefits of REDD+. The study then concludes with a set of policy reflections based on the results of the problem representation analysis to encourage policymakers or practitioners to self-reflect on the "problems" that are usually taken for granted, especially during the policy formulation or program proposal stages of climate change mitigation related to forest management, and to evaluate multiactor collaboration to include alternative problematization constructs for the collective goal of helping Laos achieve its forest cover target.

\footnotetext{
2 http://www.fao.org/laos/news/detail-events/en/c/454719/ (accessed on October 15, 2019)

${ }^{3}$ Laos 2014 country report preparing for FAO Global Forest Resources Assessment 2015 (FRA 2015)

${ }^{4} 2015$ Survey showed forest cover at $58 \%$ and might reach $68 \%$ by 2020. See more in Vientiane Times May 30, 2019 http://annx.asianews.network/content/2020-target-70-cent-forest-cover-unlikely-be-met-report-97550 (Accessed on October 14, 2019)
} 


\section{Theoretical Framework on Problem Representation}

"How are we governed" and "what kind of impact is so managed" are the key aspects of problematization exercises that originated in the governmentality concept first popularized by Foucault (1980). Previously, scholars also discussed how the choice of concepts is pivotal for politics and lawmaking as well as individual actions (Christie and Bruun, 1969). Such views or qualitative analysis approaches attracted a group of Critical Discourse Studies (CDS) scholars, e.g., in the Discourse \& Society journal ${ }^{5}$, to examine these complex social phenomena via multidisciplinary and multimethodical approaches (Dijk, 1984).

In 1999, the "What is the Problem Represented to be?" approach was initiated by Bacchi (1999) and subsequently applied by other public policy researchers (Bacchi, 2009, 2012; Hutchinson and Eveline, 2010; Pereira, 2014). The premise of the WPR rests upon the view that if the aim of policymaking or policy reform is to "fix" a problem, then the "problem" to solve dictates the direction of rulemaking and implementation and thus requires problem "questioning". In such problem representation analyses, "policy is not a reaction to 'problems' that sit outside the process waiting to be 'addressed' or 'solved'(Bacchi, 2015). Rather, policy is socially constructed by the policymakers' own problem representation construct during the policy formulation or program proposal stage. In other words, problem representation analysis is rooted in the poststructuralist observation that actors formulate "problems" differently, and these differences guide their corresponding actions, solutions, and beliefs and generates various impacts on the problem one wishes to tackle. Therefore, such analyses are not performed to find the correct policy response to the complex policy issue, such as emission reductions, but to examine how REDD+ is "questioned, analyzed, classified and regulated"(Deacon, 2000) in the problematization pattern construct of various agents. By unraveling the heterogeneous methods of problem representation and dissemination, new approaches can be revealed and created to disrupt the existing structures while introducing or supplementing alternatives to innovative future governmentality.

\subsection{Laos Case Context and Method}

\subsection{Laos REDD+}

Southeast Asia is known to have the highest deforestation rate in the world, which is approximately twice that of Africa or South America (Lepers et al., 2005). In particular, the Lao PDR, which has a population of 6.6 million, $23.2 \%$ of which is below the national poverty line ${ }^{6}$, has the highest percentage of forest to land area in Southeast Asia (68\%) compared with Malaysia (62\%), Indonesia (52\%), Vietnam (44\%) and Philippines (26\%) based on statistics quoted in the Food and Agriculture Organization of the United Nations 2016 report on the Current Status of Forest Concessions in Southeast Asia ${ }^{7}$. Although Laos has striven to develop economically since the 1980s, the country began to experience forest loss around the same period, and the forest cover was nearly $50 \%$ in 1982 and decline to $40 \%$ of the total land area by 2010 (Vongsiharath, 2011). The widespread decrease of forest quality was also observed, with dense forest declining from $29 \%$ to $8.2 \%$ from 1992 to 2002 and open forest increasing from 16\% to 24.5\% (Moore et al., 2011).

To combat deforestation and forest degradation, Laos has participated in numerous REDD+related payment for ecosystem service schemes or subnational initiatives, such as the Forest Investment Program (FIP) or a Lao-Germany cooperative program entitled "Climate Protection

\footnotetext{
${ }^{5}$ https://journals.sagepub.com/home/das (accessed on December 9, 2018)

${ }^{6}$ Asian Development Bank, Basic Statistics 2018 https://data.adb.org/dashboard/lao-peoples-democratic-republicnumbers (accessed December 11, 2018)

${ }^{7}$ http://www.fao.org/forestry/45022-0f557d8566880c29ada8b134400e42c4e.pdf (accessed on October 14, 2019) see Table 3 on p. 3
} 
through Avoided Deforestation (CliPAD) program. Although the former aims to scale up the sustainable management of Laos' forest management to promote carbon sequestration and livelihood security with a total project cost of nearly US\$ 40 million $^{8}$ (2013-2019), the latter provides policy advice and capacity building to assist the Government of Lao PDR (GoL) to plan and execute REDD+ Readiness Process at national and subnational levels 9 . In 2008, when the FCPF was founded, Laos became one of first 14 country participants, and in 2009, its REDD Readiness Preparation Proposal (R-PP) grant was signed. In 2014, US\$ 8 million of the FCPF Readiness Fund was committed (FCPF, 2018a). In late 2015, Laos was accepted for inclusion in the Carbon Fund preparation and will be rewarded based on performance up to US\$35 million for REDD+ from 2018 to $2024^{10}$.

In terms of forest ownership and governance style, Laos, Cambodia and Myanmar are the three countries in Southeast Asia where forests are owned $100 \%$ by the state ${ }^{11}$. Forest management policy in Laos is primarily driven by a top-down approach dictated by a one-party communist political system, which increases the difficulty of openly criticizing government-devised REDD policies. Baird (2014) echoed this view by addressing the difficulty of the REDD requirement to enable participation by Free, Prior and Informed Consent (FPIC). Other researchers also discussed how the absence of brokers between state and nonstate actors in Laos might lead to limited information flow and a fragmented REDD+ policy arena, which will result in an inefficient institutional setup for leveraging the adaptive management required for REDD+ (Vongvisouk et al., 2016)

\subsection{Research Design}

This research design aims to explore how the problems of deforestation and forest degradation are represented in the contentious REDD+ policy arena to reveal and promote an alternative knowledge base for future policy guidance. By applying a method of analyzing problem representations in Lao PDR, a Southeast Asian countries with a challenging deforestation problem, multiple data sources were collected and analyzed to capture problem representations constructed by state and nonstate actors in Laos REDD+ (see Figure 1). In this design, problems represented by REDD+ country reports and policy/law data are referred to as the business as usual scenario (BAU), and they reflect the one-party centralized politics of Laos in the existing governing style, whereas problems represented by online news, academic papers and NGO reports symbolize the views of nonstate actors and alternative REDD+ point of reflections by multiactor governance.

A comparative analysis of five different data sources was performed to investigate the problematization gap based on three aspects of the REDD+ programs in the Lao PDR, i.e., 1) general REDD+, 2) drivers of deforestation and degradation (DD), and 3) noncarbon benefits of REDD+, by using NVivo 12, which is a qualitative analysis tool that assists in pattern identification and categorization in semiotic data analysis. Specifically, the design of first aspect follows a backward casting method to deduce how certain policies produce a "problem" by posing two main questions proposed by Bacchi in the WPR: Q1 - what is the problem and 4) what is left unproblematic (Bacchi and Goodwin, 2016). Question 2, 3, 5 and 6 based on the WPR approach, which explore the assumptions, "problem" origins, effects and how the problem is disseminated via discourse, could not be analyzed based on the current data collection method. This research hereby recognizes the limits of the current method and calls for future research, such as in-depth interviews with Lao

\footnotetext{
${ }^{8}$ More information can be found at the LA-Scaling-Up Participatory Sustainable Forest Management project page of the World Bank http://projects.worldbank.org/P130222/la-scaling-up-participatory-sustainable-forestmanagement?lang=en (accessed on December 11, 2018)

${ }^{9} \mathrm{http} / / /$ clipad-laos.org/ (accessed on December 11, 2018)

${ }^{10}$ REDD+ in Laos FCPF Carbon Fund accepts the Lao Program https://snrd-asia.org/good-news-for-redd-in-laos-fcpfcarbon-fund-accepts-lao-programme-idea-note/ (accessed on December 11, 2018)

${ }^{11}$ See footnote 11 of Table 3 in the FAO 2016 report
} 
government officials or nongovernmental organizations, to understand the deep-routed presuppositions, genealogy, impacts and defenses of the problem representation.

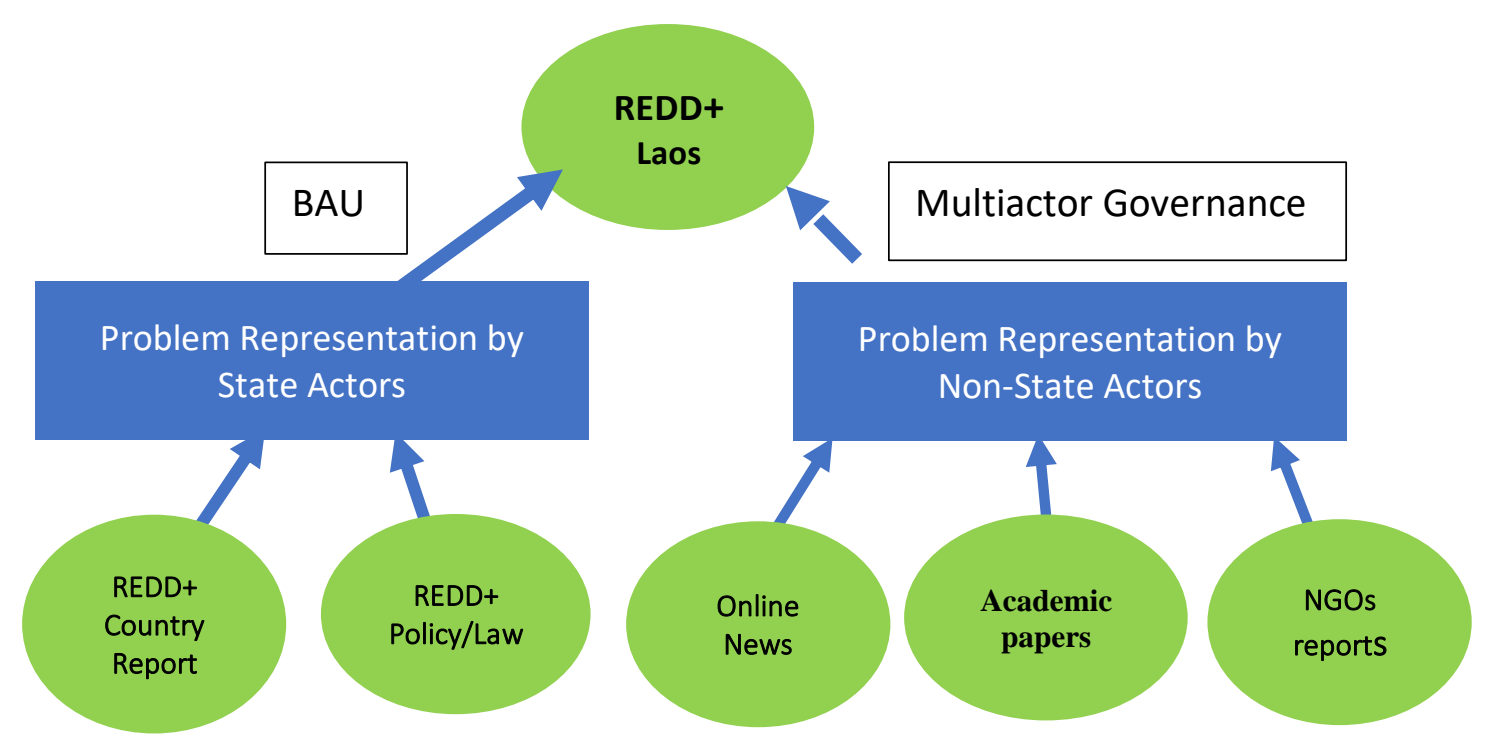

Figure 1. Problem Representation Analysis Design for Laos REDD

Source: drawn by author

\subsection{Data Collection}

Multiple sources of data were collected in this study to examine the heterogenous strategy of problematizing REDD+ by multiple actors. A total of five different sources of data was gathered to represent state and nonstate actors: FCPF Laos country reports, Laos law- or REDD-related policies, online news, academic papers and NGO reports. Although FCPF country reports and REDD+related laws or policies contain problem representations constructed by the Government of Laos (GoL), online news represents views from the media and general interests of broader readers; academic papers record scientific findings and policy recommendations from academia and the research community; and NGO reports reflect the concerns of civil society organizations (CSOs) at the national and international levels on the status of climate change mitigation and forest management in Laos.

Table 1. Multiple Source Data Collection for REDD+ in Laos

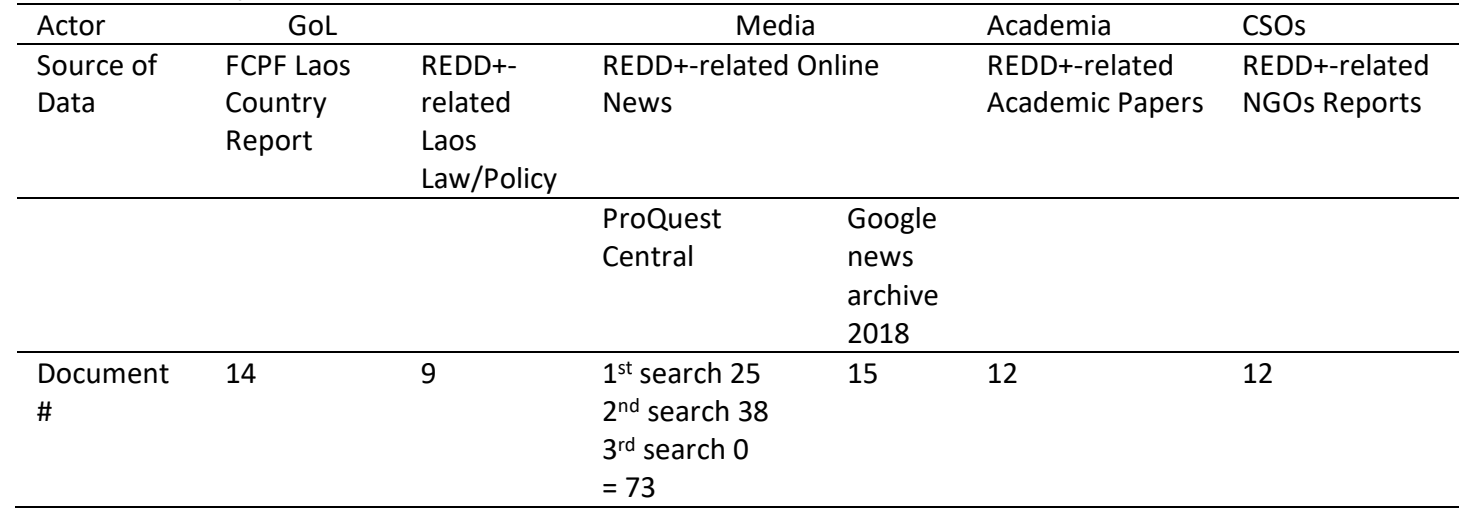

Source: compiled by author 
This research retrieved 14 of the latest Laos FCPF country reports from 2015-2018 from the website of FCPF, which provides Laos a significant portion of total REDD+ funding ${ }^{12}$, to be included in the analysis along with extra 9 REDD+-related laws or policies promulgated by the Laos government to supplement the official problem representation on forest-linked ER strategies, such as the Prime Minister's decree NO. 15/PM (released on May 2016) to strengthen timber transport and trade, Laos Forest 2020 Strategy or Law on Land No. 04/NA dated 2013 (see Table 1).

Due to data access and availability, online news, instead of offline news, was mainly collected from the ProQuest Central database and supplemented by Google Newspaper Archive. In November 2018, three searches were conducted with ProQuest Central. First, ProQuest Central performed a search of English news from 2010-2018 using "Laos" and "REDD" as the keywords, and it only yielded 76 news results. Among these results, 25 new stories were selected by the researcher upon manual screening for relevance. A second similar search was conducted with the keywords "land" and "deforestation", and it yielded 406 news results. However, after excluding the repeated news stories from the first search, only 38 news reports were included in the analysis. In the last search with the keyword "Laos forest carbon partnership", 64 results were returned; however, 0 results were chosen due to their repeated nature or irrelevance. To further supplement the data on 2018 news, the most relevant 15 news reports from Google Newspaper Archive were retrieved using keyword "Laos forest carbon".

As for academic papers and NGOs reports, the researchers selected the 12 most-relevant REDD+ papers from Google Scholar and 12 reports from websites of various nongovernmental agencies, including The Center for People and Forests, Forest Trends, Japan International Volunteer Center and Lao Biodiversity Association, etc. Once the multiple source data were collected, all data were imported to NVivo 12 for further computer-assisted semiotic pattern identification and manual comparative problem representation analysis by the researchers using the WPR framework.

\section{Problem Representation Analysis Results}

The results of the problem representation analysis are divided into three parts to demystify REDD+ practices in Laos: 1) general REDD+ "problem" representation; 2) "problem" of deforestation and forest degradation drivers; and 3) "problem" of REDD+ noncarbon benefits. In each part, the WPR framework were applied by the researcher during the comparative problem representation analysis to reflect the heterogeneity of problem taken for granted or neglected.

\subsection{General REDD+ "Problem" Representation Comparative Analysis}

By using NVivo, a computer assisted qualitative analysis tool, different REDD+-related "problem representation" patterns formulated by different actors can be compared based on a comparative word cloud analysis (Figure 2) and word count percentage, which are summarized in Table 2.

Problem representation similarities among the four actors are found in three categories: 1) importance of "land"; 2) importance of "community"; and 3) importance of "development". Although the frequency of mentioning these three words varies, all four actors agreed on the important role that "land" and "community" played in tackling emission reductions and forest management. In addition to the Lao government, media $(0.37 \%)$, academia $(0.46 \%)$ and CSOs (1.10\%) further emphasized the "development" aspect of Laos REDD+ programs. In particular, CSOs discussed a myriad of "development" aspects that can be relevant or useful in forest-based emission reduction programs, and they include "capacity", "economic", "enterprise", "gender", "hydropower", "infrastructure", "institutional", "international", "land", "leadership", "local", "rural", "sustainable" or "upland" development, etc. Surprisingly, the GoL was silent about

12 FCPF Lao PDR website https://www.forestcarbonpartnership.org/lao-people\%E2\%80\%99s-democratic-republic (accessed on December 11, 2018) 
"development" (0\%), which implies an area that can be strengthened by the Lao government in future policy planning. For academia, "development" is generally discussed under "international", "rural" and especially "upland" contexts.

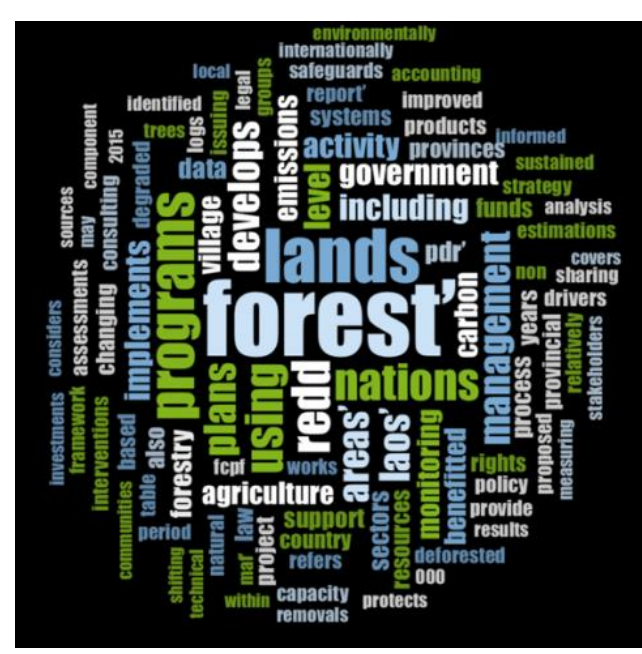

GoL

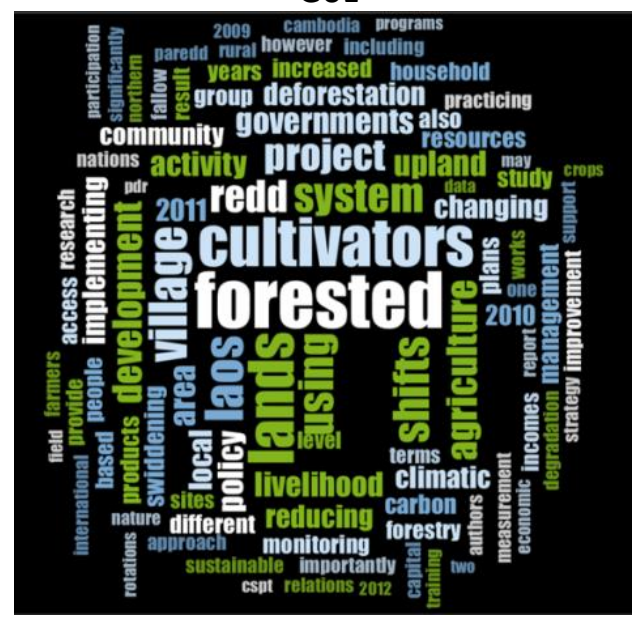

academia

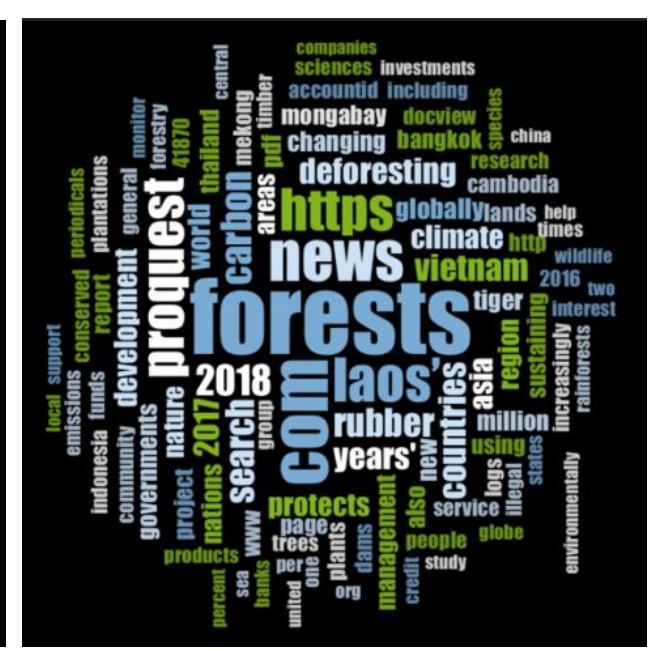

media

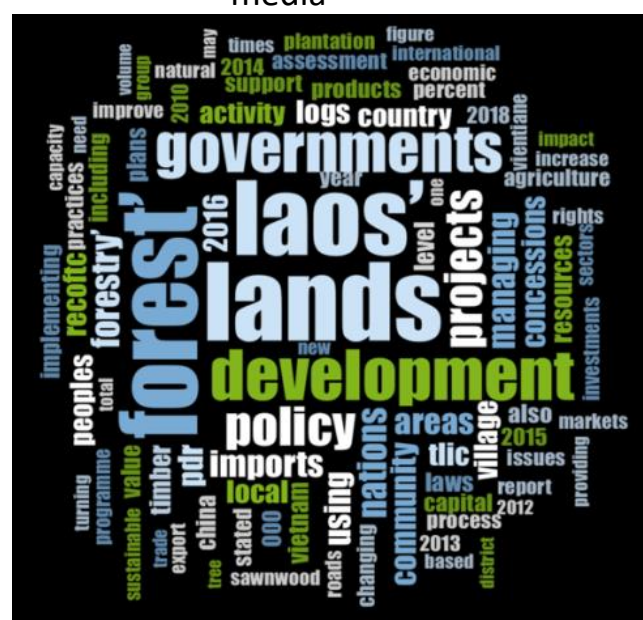

CSOs

Figure 2. Comparative Word Count Cloud Analysis

Source: NVivo analysis conducted by author

Table 2. General Comparative WPR Q1 Analysis (Source: compiled by author)

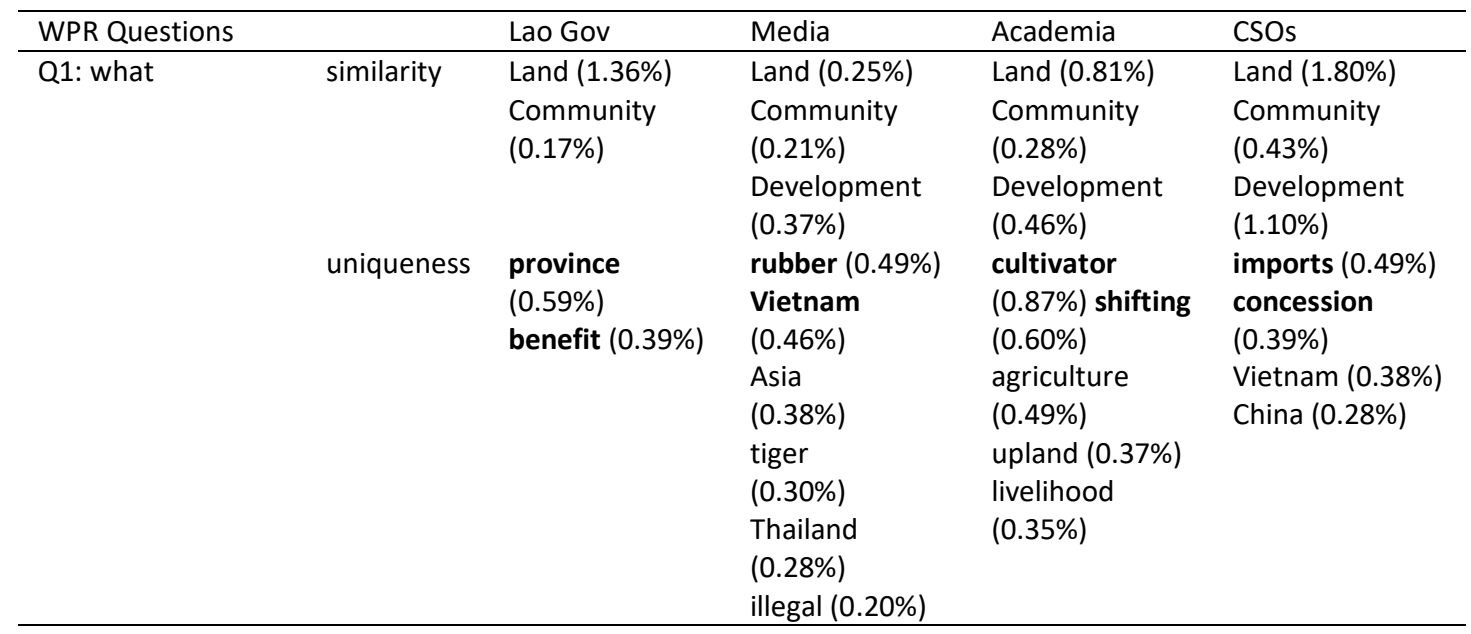


The four actors are differentiated based on their unique problem representations. For the GoL, the "problem" of REDD+ is closely linked to the efforts of "province" (0.59\%), which is not emphasized by other actors. The "benefits" $(0.39 \%)$ of REDD+, including carbon or noncarbon benefits, is also a recurrent term mentioned in the governmental documents but relatively ignored in the online news reports, where their only received $0.04 \%$ of the word count, thus reflecting either a lack of interest from the media or a lack of anecdotal evidence for a news story to disseminate. The media's attention is more concentrated on the effort or need of other nations to collectively solve the emissions reduction problem with Laos. "Vietnam" $(0.46 \%)$, "Thailand" $(0.28 \%)$ or "Asia" $(0.38 \%)$ in general were mentioned recursively. The research community, on the other hand, provides scientific evidence on the relationship among "shifting" $(0.60 \%)$, "agriculture" $(0.49 \%)$ and forest degradation, particularly in the "upland" $(0.37 \%)$ of Laos. Last, in discussing forest management, CSOs problematize the concept of "concessions" $(0.39 \%)$ largely in terms of "land" but also in terms of "logging", "mining", "large infrastructure", "investment" or "agriculture", etc.

Table 3. WPR Q4 Comparative Analysis

\begin{tabular}{|c|c|c|c|c|c|}
\hline WPR Questions & & Lao Gov & Media & Academia & CSOs \\
\hline Q2: assumption & \multirow{2}{*}{\multicolumn{5}{|c|}{ Future research needed }} \\
\hline Q3: genealogy & & & & & \\
\hline \multirow[t]{2}{*}{ Q4: silence } & $\begin{array}{l}\text { similarity } \\
\text { gap }\end{array}$ & $\begin{array}{l}\text { Development } \\
(0 \%)\end{array}$ & -------- & -------- & -------- \\
\hline & $\begin{array}{l}\text { uniqueness } \\
\text { (weighted } \\
\%>0.1 \% \text { ) }\end{array}$ & $\begin{array}{l}\text { import }(0 \%) \\
\text { tiger }(0 \%) \\
\text { Asia }(0 \%) \\
\text { Thailand }(0 \%) \\
\text { Vietnam } \\
(0.02 \%) \\
\text { upland }(0.04 \%) \\
\text { rubber }(0.04 \%) \\
\text { illegal }(0.08 \%) \\
\text { concession } \\
(0.08 \%)\end{array}$ & $\begin{array}{l}\text { shifting }(0 \%) \\
\text { upland }(0 \%) \\
\text { concession } \\
(0.03 \%) \\
\text { benefit }(0.04 \%) \\
\text { livelihood } \\
(0.07 \%) \\
\text { province }(0.09)\end{array}$ & $\begin{array}{l}\text { tiger (0\%) } \\
\text { import (0\%) } \\
\text { illegal }(0.01 \%) \\
\text { concession } \\
(0.01 \%) \\
\text { China }(0.01 \%) \\
\text { Thailand } \\
(0.02 \%) \\
\text { Vietnam } \\
(0.03 \%) \\
\text { rubber }(0.04 \%) \\
\text { benefit }(0.06 \%) \\
\text { Asia }(0.07 \%) \\
\end{array}$ & $\begin{array}{l}\text { tiger }(0 \%) \\
\text { shifting }(0.03 \%) \\
\text { upland }(0.05 \%) \\
\text { Asia }(0.06 \%) \\
\text { rubber }(0.06 \%) \\
\text { Thailand } \\
(0.06 \%) \\
\text { illegal }(0.08 \%)\end{array}$ \\
\hline \multicolumn{6}{|l|}{ Q5: effect } \\
\hline Q6: dissemination & \multicolumn{5}{|c|}{ Future research needed } \\
\hline
\end{tabular}

Source: compiled by author

The current method, nevertheless, can reveal ignored issues or unproblematic issues (Question 4) by cross comparing the semiotic data of the four actors. Interestingly, the GoL does not consider the terms "import" (0\%), "tiger" (0\%), "Asia" (0\%) and "Thailand" (0\%) as relevant to the REDD+ problem or solution. Similarly, academia did not consider the terms "tiger" or "import" as relevant to the problem while CSOs did not mention "tiger" $(0 \%)$ at all in their problem representation. The media is comparatively silent on shifting, agriculture and upland.

The above analysis showcases how the six questions proposed by the WPR approach can be systematically posed in order. However, those questions can also serve as a guideline for performing an integrated analysis (Bacchi, 2015). The following two subsessions 4.2 and 4.3 will investigate the "problem representation" of deforestation and forest degradation drivers and noncarbon benefits of REDD+, respectively. The following analyses will also disproportionately focus on the Lao government source of data to problematize the existing policymaking and implementations. 


\section{2 "Problematization" of Deforestation and Forest Degradation Drivers}

From an official point of view, the Lao government listed numerous direct and indirect drivers that contribute to deforestation and forest degradation (see Figure 3). However, whether the Lao government has taken or will take action to tackle these drivers to reduce deforestation and forest degradation is a key issue for further scrutiny.

\begin{tabular}{|c|c|c|}
\hline Activity & Indirect/underlying & Direct \\
\hline \multirow[t]{2}{*}{$\begin{array}{l}\text { Forest } \\
\text { degradation }\end{array}$} & $\begin{array}{l}\text { - Weak governance, limited resources and institutional } \\
\text { capacity } \\
\text { - Poverty (Lao PDR is an LDC) } \\
\text { - Population growth } \\
\text { - Shift in rural livelihoods from subsistence-based to } \\
\text { market-based } \\
\text { - Limited trade/market access for non-shifting } \\
\text { agroforestry and fruiting crop commodities } \\
\text { - Displacement of subsistence agricultural plots into } \\
\text { - } \text { natural forests } \\
\text { - Issued security requirements of rural population tenure and forest access insecurity }\end{array}$ & $\begin{array}{l}\text { Pioneering shifting cultivation for expansion of } \\
\text { agricultural area }\end{array}$ \\
\hline & $\begin{array}{l}\text { - Weak governance, limited resources and institutional } \\
\text { capacity } \\
\text { - High international demand for timber } \\
\text { - Quotas allowed for salvage logging alongside } \\
\text { infrastructure projects etc. }\end{array}$ & Legal and illegal selective logging \\
\hline \multirow[t]{4}{*}{ Deforestation } & $\begin{array}{l}\text { - Weak governance, limited resources and institutional } \\
\text { capacity } \\
\text { - International demand for agricultural crops as food } \\
\text { and other inputs } \\
\text { - incomplete land use zoning and titling }\end{array}$ & $\begin{array}{l}\text { Concessions and contract farms converting } \\
\text { forests (or once shifting cultivation sites) into } \\
\text { agricultural areas }\end{array}$ \\
\hline & $\begin{array}{l}\text { - Weak governance, limited resources and institutional } \\
\text { capacity } \\
\text { - International demand for agricultural crops as inputs } \\
\text { (feed, paper, rubber etc.) and national development } \\
\text { strategies in support }\end{array}$ & $\begin{array}{l}\text { Concessions and contract farms converting } \\
\text { forests (or once shifting cultivation sites) into } \\
\text { industrial tree plantations }\end{array}$ \\
\hline & $\begin{array}{l}\text { - Weak governance, limited resources and institutional } \\
\text { capacity } \\
\text { - International demand for minerals and national } \\
\text { development strategies in support }\end{array}$ & Mining projects converting forests \\
\hline & $\begin{array}{l}\text { - Weak governance, limited resources and institutional } \\
\text { capacity } \\
\text { - International demand for electricity and national } \\
\text { development strategies in support }\end{array}$ & Hydropower infrastructure converting forests \\
\hline
\end{tabular}

Figure 3. Drivers of DD Identified by the Lao Government Source: adapted from Table 5.1 a in the Lao PDR FCPF Carbon Fund ER-PIN report (FCPF, 2015)

Based on a poststructuralist perspective, action is taken based on presumptions or a set of taken-for-granted attitudes (Harcourt, 2007). To deconstruct the action in our writing or everyday life under pre-existing structures requires an understanding of the ethical choices made based on our version of social environment. In other words, the ethical choices made by the Lao government can be studied by examining the "actions" taken. The below analysis matches the drivers of deforestation and degradation identified by Lao officials with a set of REDD+ actions, i.e., emission reduction and forest management strategies, policies or law (Table 4), and critically identifies the problems that are "assumed", "unproblematic" or silent and how the problem representation is disseminated. 
Table 4. Identified Drivers vs Current Lao REDD+ Strategy Comparison

\begin{tabular}{|c|c|c|}
\hline & $\begin{array}{l}\text { REDD+ Law/Political commitment } \\
\text { (FCPF, 2018c) }\end{array}$ & $\begin{array}{l}\text { Current REDD+-related government policies } \\
\text { (FCPF, 2018c) p. } 25\end{array}$ \\
\hline & $\begin{array}{l}\text { Prime Minister's Order No. } 15 \text { of } \\
2016 \\
\text { - Enforce the ban on the export } \\
\text { of logs and unprocessed timber } \\
\text { to avoid illegal logging }\end{array}$ & $\begin{array}{l}\text { 8th National Socio-Economic Development Plan } \\
\text { (NSEDP: 2016-2020) } \\
\text { - } \quad \text { Balance economic development with natural } \\
\text { resources management } \\
\text { - } \quad \text { Achieve } 70 \% \text { forest cover by } 2020 \\
\text { - } \quad \text { Recovery of forest resources }\end{array}$ \\
\hline \multirow{2}{*}{$\begin{array}{l}\text { Corresponding } \\
\text { Drivers }\end{array}$} & Illegal logging & $?$ \\
\hline & $\begin{array}{l}\text { EU Voluntary Partnership Agreement } \\
\text { for Forest Law Enforcement, } \\
\text { Governance and Trade (FLEGT) }\end{array}$ & $\begin{array}{l}\text { National Green Growth Strategy (early } 2018 \\
\text { version) } \\
-\quad \text { Reach and maintain 70:30 ratio land balance }\end{array}$ \\
\hline \multirow[t]{2}{*}{$\begin{array}{l}\text { Corresponding } \\
\text { Drivers }\end{array}$} & $\begin{array}{l}\text { Legal and Illegal logging } \\
\text { High international demand on timber }\end{array}$ & $?$ \\
\hline & $\begin{array}{l}2016 \text { reconsolidation of ER } \\
\text { management into one single ministry } \\
\text { - MAF } \\
\text { - In 2011, separation of forestry } \\
\text { sector between MAF and } \\
\text { MONRE } \\
\text { - } \quad \text { Set up National REDD+ Task } \\
\text { Force }\end{array}$ & $\begin{array}{l}\text { Forestry Strategy } 2020 \\
\text { - } \quad \text { Forest Regenerate up to } 6 \text { million ha } \\
\text { - } \quad \text { Provide sustainable flow of forest products to } \\
\text { increase job } \\
\text { - } \quad \text { To preserve species and habitats } \\
\text { - } \quad \text { To conserve environment }\end{array}$ \\
\hline \multirow{2}{*}{$\begin{array}{l}\text { Corresponding } \\
\text { Drivers }\end{array}$} & ? weak institution? & $?$ \\
\hline & $\begin{array}{l}\text { Forest Law enforcement and revision } \\
-\quad \text { emphasized by Dept. of Forest } \\
\text { Inspection (DOFI) } \\
\text { - } \quad \text { SUFORD-SU }\end{array}$ & $\begin{array}{l}\text { Intended Nationally Determined Contributions } \\
\text { (INDC) } \\
\text { - Increase and maintain forest cover at } 70 \% \text { as } \\
\text { GHG sinks } \\
\text { - Achieve sustainable community forest } \\
\text { management }\end{array}$ \\
\hline \multirow[t]{2}{*}{$\begin{array}{l}\text { Corresponding } \\
\text { Drivers }\end{array}$} & $\begin{array}{l}\text { Illegal logging } \\
\text { Weak institution }\end{array}$ & $?$ \\
\hline & $\begin{array}{l}\text { Land laws and revisions } \\
\text { - } \quad \text { PM's Decree on Implementation } \\
\quad \text { of the Land Law (2008) } \\
\text { - } \quad \begin{array}{l}\text { Resolution on Land (2017) to } \\
\quad \text { reduce land conflicts }\end{array} \\
\end{array}$ & \\
\hline $\begin{array}{l}\text { Corresponding } \\
\text { Drivers }\end{array}$ & $\begin{array}{l}\text { Incomplete land use and titling } \\
\text { Weak institution }\end{array}$ & \\
\hline
\end{tabular}

Source: compiled by author

A cross examination of 4 current REDD+ Lao government strategies, i.e., The 8th National SocioEconomic Development Plan (NSEDP: 2016-2020), National Green Growth Strategy (early 2018 version) ${ }^{13}$, the Forest Strategy 2020 (2005, subject to update 2019) and Intended Nationally Determined Contributions (INDC, 2015 submission), showed that although all four reports are unambiguous about Laos' national goal of achieving $70 \%$ forest cover, which represent the original state in 1940, by 2020 and maintaining the 70:30 ratio land balance for land conservation and development objective, the actions taken are ambiguous and unclear about how to respond to the specific identified drivers. According to the latest forest survey conducted by the Lao government (PDR, 2018), the forest cover for 2015 was $57.4 \%$ (defined by an area of minimum of $20 \%$ canopy density) and dominated by mixed deciduous forest. However, this figure is still far from the 2020

\footnotetext{
${ }^{13}$ Laos National Green Growth Strategy is drafted based on the outcome of the NSEDP and policy recommendations made by Global Green Growth Institute in Green Growth Potential Assessment: Lao PDR Country Report November 2017.
} 
goal of $70 \%$, which will not be reached unless extreme measures are taken to mitigate the effects of deforestation and degradation drivers.

Similarly, based on the annual tree cover loss by dominant drivers in Laos according to the Sustainability Consortium, World Resources Institute and University of Maryland on Global Forest Watch platform ${ }^{14}$, the rate of permanent deforestation is not slowing down but increasing, especially in managed forest and tree plantation areas after the introduction of the main Laos official forest management guideline, Forest Strategy 2020, in 2005.

The latest political commitment or REDD+-related law revision plans, however, show the greater determination of the GoL to tackle the drivers of DD. In particular, the problem of "illegal logging" triggered several government actions, which assume that the rule of law or a strong institution is pivotal to the implementation of REDD+. The Prime Minister's decree No. 15 (2016) and a call for enforcement and revision of Forest Law reflect the assumption that the Lao government seeks to strengthen the role of Dept. of Forest Inspection (DOFI) and use the SUFORDSU sustainable forestry project to support forest law enforcement in 18 provinces (FCPF, 2018c). The indirect driver "high international demand for timber" is also a focus of the Lao government to accept the EU initiative and enter the EU Voluntary Partnership Agreement for Forest Law Enforcement, Governance and Trade (FLEGT) ${ }^{15}$. The main purpose of the FLEGT is to create opportunities for Lao timber to enter the EU market, facilitate future technology transfer to Lao timber industry, ensure the sustainable development of forest sector and raise awareness of the benefits of legal timber trading ${ }^{16}$.

Furthermore, the 2016 consolidation effort of designating one single ministry, i.e., the Ministry of Agriculture and Forestry (MAF), was performed to fix the "problem" of weak institutional capacity or coordination when REDD+ programs were separately initiated by MAF and MONRE (Ministry of Natural Resources and Environment) since 2011. By setting up a National REDD+ Task Force ${ }^{17}$, the Lao government is pooling all available resources so that they are centrally coordinated and improving decision-making and implementation efficiency (FCPF, 2018c). Land Law reform is then performed to fix the "problem" of unclear land titling that caused many land conflicts in agricultural or forestland management and address the problematic reality that over $80 \%$ of land leases and concessions are in the hands of foreign investors primarily from Vietnam, China and Thailand. Among which, approximately $30 \%$ of the land that is leased or concessioned is forest and $38 \%$ of the land investment is in the northern region (FCPF, 2018c), which is primarily occupied by ethnic minorities in mountainous or upland area.

Last, the current Laos REDD+-related strategies or laws are relatively "silent" or have not directly addressed the problematic drivers of "mining projects converting forests" and "hydropower infrastructure converting". However, in the future strategy submitted to the FCPF, the Lao government has included "infrastructure and mining development, including resettlement and urban expansion, in coordination with forest protection" as one of their five strategies for forestrelated emissions reductions (FCPF, 2018b).

\section{3 "Problematization" of REDD+ Non-Carbon Benefits}

Of the 14 latest FCPF country reports submitted by the Lao government, 10 reports mentioned "noncarbon benefits". In particular, the Technical Assessment of the Final Draft ER Program

\footnotetext{
${ }^{14} \mathrm{https}: / /$ www.globalforestwatch.org/dashboards/country/LAO?treeLossTsc=eyJoaWdobGInaHRIZCI6ZmFsc2UsInRocmV zaG9sZCI6MjB9\&widget=treeLossTsc (accessed on December 14, 2018); five drivers are identified in their study: commodity-driven deforestation, shifting agriculture, large-scale forestry operation, wildfire, and urbanization. 15 The first negotiation meeting of the FLEGT VPA between the Lao PDR and European Union took place in Vientiane, Laos from 27-28 April, 2017. http://www.euflegt.efi.int/laos (access on December 14, 2018)

16 For additional information, visit https://flegtlaos.com/ (access on December 14, 2018)

17 http://dof.maf.gov.la/fcpflao/en/national-redd-task-force/ (access on December 14, 2018)
} 
Document of Laos in 2018 demonstrates a high word frequency (93 times). Within the WPR approach, when the genealogy of "noncarbon benefits" is posed as a "problem", the origin can be traced back to the FCPF requirement for all fund applicant countries to follow the Carbon Fund Methodological Framework, which constitutes a set of 37 criteria and related indicators (C\&I) (FCPF, 2016). Criterion 16 on community participation in monitoring and report, for instance, demands that the ER Program demonstrates an effort to safeguard the "noncarbon benefits" for the local community. A Benefit-Sharing Plan is also requested in Criterion 33 to regulate such benefits via national laws or national obligations under international laws. In short, the problem of "noncarbon benefits" is largely designed by the Lao national government based on external pressure from the wider international financial scheme required by the FCPF rather than driven by internal needs or domestic voluntary proposals. The foci of noncarbon benefits in the Lao PDR are summarized in Table 5.

Table 5. Priority Non-Carbon Benefits by Category

\begin{tabular}{l|ll}
\hline & Noncarbon benefits & Priority \\
\hline Social & Reduced poverty incidence & Yes \\
& Enhanced food security & Yes \\
& Increased participation (women/ethnic groups) & Yes \\
& Increased knowledge and skill among rural ethnic communities & Yes \\
& Recognition of local knowledge and customary use of forests & Yes \\
\hline Environmental & Watershed protection & Yes \\
& National habitat conservation for biodiversity & Yes \\
& Increased forest restoration/rehabilitation & Yes \\
\hline Governance & Increased participation in forest management & \\
& Improved land tenure security & \\
& Improved capacity for law enforcement, monitoring and reporting &
\end{tabular}

Source: modified from Table 16.1.b in p. 217-218 (FCPF, 2018c)

In the FCPF ER report submitted by the Lao MAF, noncarbon benefits are divided into three categories, i.e., socioeconomic, environmental and governance, for a total of 12 types of cobenefits. Although the GoL reported priority areas in 8 cobenefits, the noncarbon benefits "increased knowledge of ethnic communities" or "recognition of local knowledge" under the socioeconomic benefit, "watershed protection" under the environmental benefit, and "transparency in decision making" under the governance benefit were left "blank" and unanswered, thus reflecting either an inability or lack of official willingness to implement current efforts to fix these "problems".

Linking the previously presented general comparative WPR analysis performed with multiple data sources with this particular section on the problem representation of "noncarbon benefits" indicates the opportunity for GoL policies to become more responsive to the problem of "tiger" (0.30\%) discussed in media. Furthermore, since the national or international CSOs revealed a high interest in the problem of "development" (1.10\%), the GoL could more actively collaborate with nongovernmental organizations, both domestic and abroad, to launch rural capacity building programs to increase the knowledge and skill of ethnic groups, especially in the forest-concentrated upland regions. Until 2018, the noncarbon benefits or "benefits" $(0.39 \%)$ of REDD+ are only listed in the FCPF reports as a funding proposal requirement and have not yet been widely disseminated through the media or academic research or confirmed by a wider civil society in their writings, pamphlets or reports. 


\section{Concluding Discussion and Policy Reflection}

Based on the above three sections on problem representation analysis, several problematization gaps associated with REDD+ programs have been identified or revealed based on different data sources to create opportunities for innovation to be introduced for future policymaking. A myriad of "problem" dimensions associated with the Lao REDD+ program have been evaluated, and alternatives have been identified during this questioning process. If climate change is regarded as a complex challenge of the $21^{\text {st }}$ century that requires a trans-disciplinary approach to identify a solution (Lang et al., 2012), then the REDD+ programs in the Lao PDR certainly need to take advantage of multiactor collaboration involving different sectors of society, including the media, academia and CSOs. In response to the problematization gaps identified based on the multiple data source analysis, four policy reflections deriving from problem representation analysis are further discussed.

1) Encourage academic research on Laos' biodiversity and watersheds: In the general REDD+ WPR analysis, academic research on Laos emission reductions and forest management concentrate on shifting agriculture and livelihood issues (see Table 2 ) but is relatively silent on biodiversity and watershed or nature conservation. Since the conservation of habitat for biodiversity and watershed are included in the priority list of noncarbon benefits, additional scientific data should be provided for evidence-based policymaking, especially for areas with a high concentration of forest cover in the northern uplands of Laos, where ethnic minorities reside.

2) Strengthen cross-sectoral collaboration between the GoL and CSOs: The analysis of the GoL and CSOs shows that they have vastly different focuses (see Table 2). Although the former emphasizes the role of "provincial" government in REDD+, the latter is concerned about the problem of "concessions" made by mostly foreign investors. Such a problem representation gap can create room for complementary cooperation between the GoL and CSOs to integrate their separate focuses to generate collective good in developmental concessions and ethnic community forest management programs.

3) Accelerate legal and judicial reform: Although Forest and Land Law revisions have been scheduled for parliamentary debate, the process has to be accelerated to provide an improved institutional environment for REDD+ to be effectively and efficiently implemented. Otherwise, the "weak institution" (see Table 4 and Figure 3) problem will be continuously listed as an "indirect driver" for many direct drivers of deforestation and forest degradation, thus leading to ineffective and inefficient REDD+ implementation.

4) Explore international or regional business cooperation frameworks: The cause of deforestation or degradation in the Lao PDR is not isolated to domestic problems, which is why a majority of media reports on REDD+ media problem representation analyzed by this study surrounds keywords of other countries, such as problems in "Vietnam", "Thailand" or "Asia" (see Table 3). To fix the fundamental cause of deforestation, the GoL could be more proactive in reaching out to neighboring countries or ASEAN to actively create sustainable business opportunities to promote legal trade and raise the value of natural commodities instead of silently allowing its natural resources to be exploited by illegal traders.

In conclusion, the aim of this paper is not to criticize or identify the best policy. The methodological design of this research follows the WPR framework as a poststructuralist method to deconstruct REDD+-related discussions performed by the government of the Lao PDR, media, research community and civil society organizations. By revealing the heterogeneity of the problem representations formulated by various actors, this research reminds researchers, policymakers and practitioners that they must explore beyond the issues that are usually taken for granted by the existing power structure. Rather than uncritically adopting a solution, the issues that are problematic and important must be reconsidered to identify new opportunities for interpreting 
methods and actions. This approach "make politics visible" (Bacchi, 2012) and "radicalizes" our senses to biases to open up a space for change (Flynn, 2005).

\section{Acknowledgments}

The author gratefully thanks to the constructive comments and insightful questions raised by anonymous reviewers during the review process. Other thanks also go to Dr. Osamu Saito at United Nations University, Institute for the Advanced Study of Sustainability for inspiring the authors into the field of sustainable bioproduction and ecosystems management.

Conflicts of Interest: The authors declare no conflict of interest

\section{References}

Bacchi, C. (1999). Women, Policy, and Politics : The Construction of Policy Problems. Sage, London, UK.

Bacchi, C. (2009). Analysing Policy : What's the Problem Represented to Be? Frenchs Forest. Pearson, N.S.W, Australia.

Bacchi, C. (2012). Why study problematizations? Making politics visible. Open Journal of Political Science, 2(01), 1-8. doi: https://doi.org/10.4236/ojps.2012.21001

Bacchi, C. (2015). Problematizations in alcohol policy: WHO's 'alcohol problems'. Contemporary Drug Problems, 42(2), 130-147. doi: https://doi.org/10.1177/0091450915576116

Bacchi, C. \& Goodwin, S. (2016). Poststructural Policy Analysis: A Guide to Practice. Palgrave Macmillan, New York, US.

Baird, I.G. (2014). Reduced Emissions from Deforestation and Forest Degradation (REDD) and access and exclusion: obstacles and opportunities in Cambodia and Laos. Southeast Asian Studies, 3(3), 643-668. doi: https://doi.org/10.20495/seas.3.3_643

Baledón, M. \& Kosoy, N. (2018). Problematizing" carbon emissions from international aviation and the role of alternative jet fuels in meeting ICAO's mid-century aspirational goals. Journal of Air Transport Management, 71(July), 130-137. doi: https://doi.org/ 10.1016/j.jairtraman.2018.06.001

Bletsas, A. \& Beasley, C. (2012). Engaging with Carol Bacchi : Strategic Interventions and Exchanges. University of Adelaide Press, Adelaide, South Australia.

Büscher, B., Sullivan, S., Neves, K., Igoe, J. \& Brockington, D. (2012). Towards a synthesized critique of neoliberal biodiversity conservation. Capitalism Nature Socialism, 23(2), 4-30. doi: https://doi.org/10.1080/10455752.2012.674149

Cavanagh, C.J., Vedeld, P.O. \& Trædal, L.T. (2015). Securitizing REDD+? Problematizing the emerging illegal timber trade and forest carbon interface in East Africa. Geoforum 60,72-82. doi: https://doi.org/10.1016/j.geoforum.2015.01.011

Christie, N. \& Bruun, K. (1969). Alcohol Problems: The Conceptual Framework. In: Keller, M. \& Coffey, T,G. (eds) Proceedings of the 28th International Congress on Alcohol and Alcoholism. Hillhouse Press, Highland Park, New Jersey. pp. 65-73.

Corbera, E. (2012). Problematizing REDD+ as an experiment in payments for ecosystem services. Current Opinion in Environmental Sustainability, 4(6), 612-619. doi: https://doi.org/ 10.1016/j.cosust.2012.09.010

Deacon, R. (2000). Theory as Practice: Foucault's Concept of Problematization. Telos 118, 127-142.

Dijk, T.A. van (1984). Prejudice in Discourse: An Analysis of Ethnic Prejudice in Cognition and Conversation. J. Benjamins Pub. Co, Amsterdam, Netherlands.

FCPF (2015). Readiness Fund REDD+ Country Participants Progress Report Lao PDR.

FCPF (2016). Carbon Fund Methodological Framework.

FCPF (2018a). Forest Carbon Partnersbhip Facility 2018 Annual Report. 
FCPF (2018b). Lao PDR FCPF Readiness Package Self-Assessment Report: Readiness for Reducing Emissions from Deforestation and Degradation (REDD+).

FCPF (2018c). Promoting REDD+ through Governance, Forest landscapes \& Livelihood in Northern LaO PDR.

Federici, S., Tubiello, F.N., Salvatore, M., Jacobs, H. \& Schmidhuber, J. (2015). New estimates of CO2 forest emissions and removals: 1990-2015. Forest Ecology and Management, 352, 89-98. doi: https://doi.org/ 10.1016/J.FORECO.2015.04.022

Flynn, T.R. (2005). Foucault's mapping of history. In: Gutting, G. (ed.) The Cambridge Companion to Foucault. $2^{\text {nd }}$ ed. Cambridge University Press, Cambridge, UK, pp. 29-48.

Foley, J.A., Defries, R., Asner, G.P., et al. (2005) Global consequences of land use. Science, 309(5734), 570-574. doi: https://doi.org/10.1126/science.1111772

Forsyth, T. (2009). Multilevel, multiactor governance in REDD+: Participation, Integration and Coordinatio. In: Angelsen, A., Brockhaus, M., Kanninen, M.N., Sills, E., et al. (eds) Realising REDD+: Natonal Strategy and Policy Options. Bogor: Center for International Forestry Research, pp. 113-122.

Foucault, M. (1980). The History of Sexuality, Vol. I. An Introduction. Vintage Books, New York, USA.

Harcourt, B. (2007). An answer to the question: 'What Is Poststructuralism?' University of Chicago, Public Law Working Paper No. 156.

Hutchinson, J. \& Eveline, J. (2010). Workplace bullying policy in the Australian public sector: Why has gender been ignored? Australian Journal of Public Administration, 69(1), 47-60. doi: https://doi.org/10.1111/j.1467-8500.2010.00669.x

Keeley, J.E. (2001). Influencing Policy Processes for Sustainable Livelihoods: strategies for change. Brighton. Institute of Development Studies.

Lang, D.J., Wiek, A., Bergmann, M., Stauffacher, M. Martens, P. Moll, P. Swilling, M. \& Thomas, C. J. (2012). Transdisciplinary research in sustainability science: practice, principles, and challenges. Sustainability Science, 7(S1), 25-43. doi: https://doi.org/10.1007/s11625-011-0149-x

Lepers, E., Lambin, E.F., Janetos, A.C., DeFries, R. Achard, F., Ramankutty, N. \& Scholes, R. J. (2005). A synthesis of information on rapid land-cover change for the period 1981-2000. BioScience, (55), 115-124. doi:https://doi.org/10.1641/00063568(2005)055[0115:ASOIOR]2.0.CO;2

Mcgregor, A., Weaver, S., Challies, E., Howson, P., Astuti, R. \& Haalboom, B. (2014). Practical critique: Bridging the gap between critical and practice-oriented REDD+ research communities. Asia Pacific Viewpoint, 55(3), 277-291. doi:https//doi.org/10.1111/apv.12064

McGregor, A. (2010). Green and REDD: Towards a political ecology of deforestation in Aceh, Indonesia. Human Geography, 3(2), 21-34.

Moore, C., Ferrand, J. \& Khiewvongphachan, X. (2011). Investigation of the Drivers of Deforestation and Forest Degradation in Nam Phui National Protected Area, Lao PDR. Climate Protection through Avoided Deforestation Programme, GIZ.

Pachauri, R., Allen, M., Barros, V., et al. (2014). Climate change 2014: synthesis report. Contribution of Working Groups I, II and III to the fifth assessment report of the Intergovernmental Panel on Climate.

PDR Ministry of Agriculture and Forestry (2018). Lao PDR's Forest Reference Emission Level and Forest Reference Level for REDD+ Results Payment under the UNFCCC.

Pearse, R. (2012). Mapping REDD in the Asia-Pacific: Governance, marketisation and contention. Ephemera: Theory \& politics in organization, 12(1-2), 181-205.

Pereira, R.B. (2014). Using critical policy analysis in occupational science research: Exploring Bacchi's methodology. Journal of Occupational Science, 21(4), 389-402. doi:https//doi.org/ 10.1080/14427591.2013.806207.

Stern, N.H. (2007). The Economics of Climate Change : The Stern Review. Cambridge University Press, Cambridge, UK. 
Vongsiharath, V. (2011). Forest Cover and Land-Use Changes in Lao PDR: According to the National forest Reconnaissance Survey. Vientiane.

Vongvisouk, T., Lestrelin, G., Castella, J.C., Mertz, O, Broegaard, R. B. \& Thongmanivong, S. (2016). REDD+ on hold: Lessons from an emerging institutional setup in Laos. Asia Pacific Viewpoint, 57(3), 393-405. doi:https//doi.org/10.1111/apv.12134

Yeboah, Y. (2013). Gendering the REDD+ policy process in Ghana. Master's Thesis. Swedish University of Agriculgture Sciences. 